\title{
Peningkatan Kemampuan Pemecahan Masalah Matematis Mahasiswa melalui Model Pembelajaran Group Investigation
}

\author{
Tanti Jumaisyaroh Siregar* \\ Pendidikan Matematika FITK UIN Sumatera Utara Medan \\ tantijumaisyaroh@uinsu.ac.id
}

\begin{abstract}
The problem solving ability of students still low the problem of this research was mathematics. The purposes of this research was to know analyze improvement in mathematics problem solving ability of students that given group investigation learning with students that given direct learning. This type of research is a quasi-experimental research. The population in this study were all students of Mathematics Education Study Program UIN North Sumatra Medan and the samples were taken by cluster random sampling based on existing classes, namely PMM-4 class as an experimental class and PMM-2 as a control class. Data collection techniques in this study were using tests of students' mathematical problem solving abilities (pre tests and post tests) in the form of essay tests. The collected data is then searched for the $\mathrm{N}$-gain value and analyzed using $\mathrm{t}$ test with SPSS 17 software.. Based of the results analysis, it showed that: Improvment of the students' mathematics problem solving ability that given group investigation learning model was higher than the students' mathematics problem solving abiliy that given direct learning. His then, suggested that group investigation learning model used for lectures to improved students' mathematics problem solving ability.
\end{abstract}

Keywords: mathematics; problem solving; model learning, group investigation; direct learning.

\begin{abstract}
Abstrak
Kemampuan pemecahan siswa yang masih rendah merupakan permasalahan utama dalam penelitian ini. Adapun yang menjadi tujuan dalam penelitian ini untuk menganalisis kemampuan pemecahan masalah matematis mahasiswa yang diberi pembelajaran dengan pembelajaran group investigation dengan mahasiswa yang diberi pembelajaran dengan pembelajaran langsung. Jenis penelitian ini adalah penelitian kuasi ekeperimen. Populasi dalam penelitian ini yaitu seluruh mahasiswa prodi Pendidikan Matematika UIN Sumatera Utara Medan dan sampelnya diambil dengan cara cluster random sampling berdasarkan kelas yang sudah ada yaitu kelas PMM-4 sebagai kelas eksperimen dan PMM-2 sebagai kelas kontrol.Teknik pengumpulan data dalam penelitian ini dengan menggunakan tes kemampuan pemecahan masalah matematis mahasiswa (pre tes dan post tes) yang berbentuk essay test. Data yang sudah dikumpulkan selanjutnya dicari nilai $\mathrm{N}$-gainnya dan dianalisis dengan menggunakan uji t dengan berbantuan software SPSS 17. Berdasarkan hasil analisis tersebut diperoleh yaitu: peningkatan kemampuan pemecahan masalah matematis mahasiswa yang diberi pembelajaran group investigation lebih tinggi daripada mahasiswa yang diberi pembelajaran langsung. Oleh karena itu, disarankan pembelajaran group investigation dijadikan sebagai salah satu model pembelajaran yang dapat diterapkan bagi dosen untuk meningkatkan kemampuan pemecahan masalah matematis mahasiswa.
\end{abstract}

Kata Kunci: matematis; pemecahan masalah; model pembelajaran; group investigation; pembelajaran langsung.

\footnotetext{
*Correspondence:

Email: tantijumaisyaroh@uinsu.ac.id
} 


\section{PENDAHULUAN}

Perkembangan ilmu pengetahuan dan teknologi dalam era revolusi 4.0 saat ini menuntut mahasiswa untuk dapat memiliki kemampuan berpikir tingkat tinggi dalam pembelajaran. Dalam pembelajaran matematika menurut NCTM terdapat lima standar proses yang hendak dicapai oleh mahasiswa yaitu kemampuan pemahaman konsep, penalaran, komunikasi, koneksi dan pemecahan masalah matematis (Mariam Nasution, 2018: 120-121). Salah satu standar proses yang wajib dimiliki oleh mahasiswa adalah kemampuan pemecahan masalah matematis.

Kemampuan pemecahan masalah matematis adalah kemampuan yang dimiliki mahasiswa dalam mencari solusi dari permasalahan yang diberikan untuk mencapai hasil yang diinginkan yang memerlukan kesiapan,kreativitas dan pengetahuan awalnya agar diterapkan dalam kehidupan nyata mahasiswa (Yarmayani, 2016:13). Selanjutnya, munurut (Amam, 2017:45) bahwa kemampuan pemecahan masalah matematis merupakan sebuah kemampuan yang dimiliki oleh mahasiswa dalam menyelesaikan masalah non rutin matematis yang berbentuk soal kontekstual yang dapat mengukur kemampuan pemecahan masalah tersebut. Berdasarkan hal tersebut dapat dikatakan bahwa pemecahan masalah yaitu kemampuan seorang siswa dalam menemukan solusi dari permasalahan non rutin berdasarkan pengetahuan awal yang dimilikinya agar dapat diterapkan dalam menyelesaikan masalah dalam kehidupan nyata mahasiswa. Selanjutnya, adapun prosedur penyelesaian masalah menurut (Polya, 1973:5) adalah: (1) memahami masalah, (2) membuat rencana permasalahan; (3) melaksanakan rencana permasalahan dan (4) memeriksa kembali.

Pada tingkat pendidikan tinggi khususnya pada prodi pendidikan matematika kemampuan pemecahan masalah matematis itu sangat penting dimiliki oleh mahasiswa. Hal ini berkaitan dengan dunia nyata mahasiswa yang akan menghadapi berbagai permasalahan. Selanjutnya, menurut Cooney (dalam Soemarmo, U dan Hendriana, 2014:23) bahwa kemampuan pemecahan masalah penting dimiliki oleh mahasiswa karena kemampuan tersebut dapat membantu mahasiswa dalam meningkatkan kemampuan berpikir analitik dan kritis untuk mengambil sebuah keputusan dalam kehidupan sehari-hari dalam menghadapi situasi baru. Selain itu, dengan memecahkan masalah matematika, mahasiswa akan memiliki cara berpikir yang sistematis, memiliki ketekunan, memiliki rasa ingin tahu, dan rasa percaya diri dalam menghadapi permasalahan yang mungkin mereka temui di luar kelas (NCTM dalam Samo, 2017:142).

Namun, kenyataan di lapangan membuktikan bahwa kemampuan pemecahan masalah mahasiswa belum mencapai hasil yang diinginkan. Berdasarkan hasil ujian tes kemampuan pemecahan masalah matematis mahasiswa menunjukkan hanya 6 orang (15\%) mahasiswa dari 40 orang 
mahasiswa yang bisa menjawab pertanyaan dengan tepat, sedangkan mahasiswa lainnya yang terdiri atas 32 orang ( $85 \%$ ) mahasiswa menunjukkan jawaban yang kurang tepat dan lengkap seperti tidak menuliskan informasi yang ada pada soal, tidak menuliskan rencana penyelesaian masalah dengan benar, tidak dapat menerapkan rumus dalam menyelesaikan masalah serta tidak dapat memeriksa kembali hasil jawaban yang telah diperoleh. Hal ini mengindikasikan bahwa kemampuan pemecahan masalah yang dimiliki oleh mahasiswa masih rendah.

Kemampuan pemecahan masalah mahasiswa yang rendah salah satunya diduga oleh pembelajaran yang dilakukan oleh dosen selama ini di Perguruan Tinggi menggunakan pola ceramah dan lebih berpusat kepada dosen serta satu arah (Siradj. Y, 2014:100). Pembelajaran yang diterapkan oleh dosen tersebut dapat juga dikatakan dengan menerapkan pembelajaran langsung. Model pembelajaran langsung merupakan pembelajaran yang dirancang untuk membantu mahaiswa mempelajarai keterampilan dasar dan memperoleh informasi yang diajarkan tahap demi tahap (Trianto, 2013:41). Adapun tahapan model pembelajaran langsung yaitu dosen menjelaskan materi, memberi contoh soal dan selanjutnya menyuruh mahasiswa mengerjakan tugas atau latihan soal. Berdasarkan hal tersebut, model pembelajaran ini tentu hanya bisa digunakan untuk mengajarkan kemampuan dasar kepada mahasiswa dan tidak dapat digunakan untuk mengajarkan mahasiwa memiliki kemampuan tinggi. Selain itu, model pembelajaran langsung juga tidak dapat melatih siswa untuk meningkatkan kemampuan berpikir tingkat tingginya.

Oleh karena itu, salah satu cara yang dapat dilakukan untuk menyelesaikan permasalahan di atas adalah dengan mengaplikasikan salah satu jenis model pembelajaran kooperatif yaitu model pembelajaran Group Investigation atau Investigasi Kelompok. Model pembelajaran ini merupakan salah satu jenis pembelajaran yang memberikan kebebasan kepada mahasiswa untuk aktif dalam menyelesaikan masalah matematika yang diberikan dengan menggabungkan anatara pengalaman dan kemampuanyang dimiliki sebelumnya antar pribadi dalam kelompok. Adapun langkah-langkah model pembelajaran group investigation menurut (Slavin, 2009) yaitu: (a) menetapkan topik materi pelajaran dan membagi siswa ke dalam kelompok-kelompok kecil; (b) membuat rencana tugas yang akan dipelajari dan mengumpulkan bahan materi; (c) melakukan investigasi terhadap permasalahan; (d) menyelesaikan laporan akhir; (e) mempresentasikan hasil laporan akhir; (f) melakukan evaluasi terhadap materi yang telah dipelajari.

Selanjutnya, dalam kegiatan pembelajaran melalui group investigation, siswa akan berpartisipasi secara aktif dan siswa akan memiliki kebebasan untuk berpikir sendiri. Siswa diikutsertakan dalam membuat perencanaankegiatan pembelajaran seperti memilih topikatau materi yanag akan mereka pelajari dan melakukan kegaiatan penyelidikan terhadap suatu permasalahan. Siswa kemudian 
diarahkan kepada penemuan konsep atau prinsip dan diharapkan dapat memahami dan mengapliaksikan konsep dengan baik serta mampu merepresentasikan hasil penyelidikan mereka dengan baik. Dari penjelasan tersebut terlihat bahwa, pembelajaran dengan group investigation memberikan peluang bagi siswa untuk dapat menemukan sendiri konsep yang mereka pelajari dan dapat memecahkan masalah yang mereka temukan (Ramon dalam Yunita, S., Andriani, L., dan Irma, 2018:12). Hal ini diharapkan dapat memperbaiki kemampuan pemecahan masalah matematis mahasiswa.

Selanjutnya, penelitian mengenai Group Investigation pembelajaran yang relevan seperti penelitian (Hija, A., Nirawati,R., dan Prihatiningtyas, 2016; Huda, 2016; Lestari, 2016; Muhandaz, 2015; Mutiawati, 2019; Ningsih, 2019) yang menunjukkkan bahwa penerapan pembelajaran Group Investigation dapat meningkatkan kemampuan pemecahan masalah siswa. Beberapa penelitian tersebut kebanyakan dilakukan dengan mengambil sampel siswa SMP dan SMA sedangkan dalam penelitian ini peneliti mengambil sampel mahasiswa prodi pendidikan matematika selaku calon guru matematika yang nantinya akan mengajarkan kemampuan pemecahan masalah kepada siswanya. Jika kemampuan pemecahan masalah yang dilakukan oleh calon guru masih rendah maka tentu ia akan kesulitan dalam meningkatkan kemampuan pemecahan masalah siswanya. Oleh karena itu, penelitian ini sangat perlu dilakukan untuk memperbaiki kemampuan mahasiswa selaku calon guru matematika. Selain itu, penelitian ini juga menggunakan media pembelajaran yaitu aplikasi android untuk membantu mahasiswa menemukan solusi dari masalah yang diberikan oleh dosen. Hal ini dikarenakan masih minimnya penggunaan media yang berbasis teknologi dalam kegiatan pembelajaran. Berdasarkan hal tersebut adapun yang menjadi tujuan penelitian ini adalah menganalisis peningkatan kemampuan pemecahan masalah matematis mahasiswa yang diajar dengan model pembelajaran Group Investigation dan mahasiswa yang diajar dengan model pembelajaran langsung.

\section{METODE PENELITIAN}

Tahapan-tahapan yang dilakukan dalam penelitian ini adalah sebagai berikut: (1) Studi pendahuluan, untuk merumuskan identifikasi masalah, rumusan masalah serta studi literarur; (2) Pengembangan perangkat penelitian berupa bahan ajar (materi), serta instrument penelitian (tes kemampuan pemecahan masalah matematis); (3) Penentuan populasi dan sampel penelitian sebagai kelas eksperimen dan kelas kontrol secara acak.; (4) Selanjutnya baik kelas kontrol dan kelas eksperimen akan diberikan soal pre test kemampuan pemecahan masalah matematis; (5) Penerapan pembelajaran Group Investigation di kelas eksperimen. Sedangkan, pembelajaran langsung diterapkan pada kelas kontrol. ; (6) Pada akhir pertemuan kedua kelas baik kelas eksperimen maupun kelas kontrol akan 
diberikan soal post test untuk diselesaikan oleh siswa berupa soal kemampuan pemecahan masalah matematis; (7) Data yang diperoleh tersebut diperiksa, disusun kemudian diolah dan dianalisis baik untuk data yang bersifat kuantitatif maupun data yang bersifat kualitatif.

Jenis penelitian ini adalah penelitian eksperimen semu atau quasi eksperiment. Penelitian ini dilakukan di Prodi Pendidikan Matematika UIN Sumatera Utara Medan. Populasi dalam penelitian ini adalah seluruh mahasiswa Prodi Pendidikan Matematika UIN Sumatera Utara Medan. Sampel penelitian dipilih secara acak (cluster random sampling) yaitu dengan mengambil kelas yang sudah ada tanpa membentu kelas yang baru. Sampel dalam penelitian ini adalah mahasiswa semester III yang terdiri atas 5 kelas pararel dimana diambil dua kelas sebagai kelas ekperimendan kelas kontrol yaitu kelas PMM-1 dan PMM-2. Dalam penelitian ini yang menjadi variabel bebasnya yaitu model pembelajaran Group Investigation dan pembelajaran langsung sedangkan yang menjadi variabel terikatnya adalah kemampuan pemecahan masalah matematis mahasiswa.

Instrumen yang akan digunakan dalam penelitian adalah tes berupa tes kemampuan pemecahan masalah matematis berbentuk essay test yang terdiri atas empat soal dimana tes diambil dari hasil penelitian yang sebelumnya yang telah diuji validiatas, reabilitas dan indeks kesukarannya. Selanjutnya, berdasarkan data pre test dan post test kan dicari nilai N-Gainnya untuk dilakukan analisis dengan uji t. Adapun uji prasyarat uji t adalah dengan menguji normalitas dan homogenitas nilai N-Gain kemampuan pemecahan masalah matematis dengan menggunakan software program SPSS 17.

\section{HASIL DAN PEMBAHASAN}

\section{Hasil Penelitian}

Hasil analisis data pada penelitian ini terdiri atas analisis statistik deskripsi dan analisis statistika inferensial. Analisis statistik deskripsi digunakan untuk menganalisis kemampuan pemecahan masalah matematis sebelum pembelajaran dan sesudah pembelajaran. Analisis statistika inferensial digunakan untuk menguji hipotesis dalam penelitian ini dengan analisis uji t. Pada pengolahan data peneliti menggunakan software SPSS 17. Setelah dilakukan pengolahan data pretes kemampuan pemecahan masalah matematis, diperoleh skor terendah $\left(\mathrm{X}_{\min }\right)$, skor tertinggi $\left(\mathrm{X}_{\text {maks }}\right)$, skor rata-rata $(\bar{X})$ dan standar deviasi $(\mathrm{SD})$ untuk kelas eksperimen dan kontrol. Untuk lebih jelasnya diuraikan pada tabel berikut ini.

Tabel 1. Hasil Pre Test Kemampuan Pemecahan Masalah Matematis

\begin{tabular}{ccccc}
\hline Kelas & $\boldsymbol{X}_{\text {min }}$ & $\boldsymbol{X}_{\text {maks }}$ & $\bar{X}$ & SD \\
\hline Eksperimen & 4 & 11 & 7,725 & 2,476 \\
Kontrol & 5 & 9 & 7,725 & 1,0374 \\
\hline
\end{tabular}


Berdasarkan Tabel. 1 di atas dapat dilihat bahwa terdapat perbedaan nilai minimum, nilai maksimum dan nilai standar deviasi data pre test kemampuan pemecahan masalah matematis mahasiswa di kelas eksperimen dan di kelas kontrol. Namun, jika dilihat berdasarkan nilai rata-ratanya bahwa terdapat persamaan kemampuan pemecahan masalah matematis mahasiswa yang di kelas eksperimen dan yang diajar di kelas kontrol yaitu 7,725. Hal ini berarti kemampuan awal pemecahan masalah matematis diantara kedua kelas tersebut tidak jauh berbeda. Selanjutnya, akan dianalisis data mengenai hasil post tes kemampuan pemecahan masalah matematis mahasiswa antara kedua kelas tersebut. Adapun data mengenai hasil post test kemampuan pemecahan maslaah matematis mahasiswa ditunjukkan pada tabel berikut.

Tabel 2. Hasil Post Test Kemampuan Pemecahan Masalah Matematis

\begin{tabular}{ccccc}
\hline Kelas & $\boldsymbol{X}_{\min }$ & $\boldsymbol{X}_{\text {maks }}$ & $\bar{X}$ & SD \\
\hline Eksperimen & 13 & 16 & 15,45 & 0,9867 \\
Kontrol & 8 & 15 & 12,775 & 1,9242 \\
\hline
\end{tabular}

Berdasarkan Tabel. 2 di atas mengenai data post tes kemampuan pemecahan masalah matematis mahasiswa di kelas eksperimen dan kelas kontrol bahwa terdapat perbedaan nilai minimum, nilai maksimum, nilai rata-rata dan nilai standar deviasi. Selain itu, data pada tabel juga menunjukkan bahwa rata-rata post tes kemampuan pemecahan masalah di kelas eksperimen lebih tinggi dibandingan dnegna kelas kontrol. Selanjutnya, akan dibahas seberapa besar peningkatan yang terjadi antara kelas eksperimen dan kelas kontrol. Peningkatan kemampuan pemecahan masalah matematis antara kelas eksperimen (yang diajarkan dengan pembelajaran Group Investigation) dan kelas kontrol (yang diajarkan dengan pembelajaran langsung) dihitung menggunakan rumus gain ternormalisasi atau N-gain. Pada pengolahan data $\mathrm{N}$-gain kemampuan berpikir kritis matematis juga diperoleh skor tertinggi $\left(X_{m a k s}\right)$, skor terendah $\left(X_{m i n}\right)$, skor rata-rata $(\bar{X})$ dan standar deviasi (SD) untuk tiap kelas sampel, dapat dilihat pada tabel berikut.

Tabel 3. Data N-Gain Kemampuan Pemecahan Masalah Matematis

\begin{tabular}{ccccc}
\hline Kelas & $\boldsymbol{X}_{\text {min }}$ & $\boldsymbol{X}_{\text {maks }}$ & $\bar{X}$ & SD \\
\hline Eksperimen & 0.4615 & 0.6667 & 0.5997 & 0.0633 \\
Kontrol & 0.25 & 0.5 & 0.4055 & 0.0636 \\
\hline
\end{tabular}

Dari Tabel. 3 di atas dapat dilihat bahwa masing-masing nilai maksimum, minimum, nilai rata-rata dan standar deviasi hasil $\mathrm{N}$-gain kelas eksperimen dan kelas kontrol berbeda. Hasil tabel di atas juga menunjukkan 
bahwa nilai rata-rata kemampuan pemecahan masalah mahasiswa diberi pembelajaran Group Investigation dan yang diberi pembelajaran langsung mengalami peningkatan. Namun, diperoleh bahwa nilai rata-rata $\mathrm{N}$-gain antar kedua kelas diperoleh bahwa rata-rata $\mathrm{N}$-gain kelas eksperimen yaitu 0.5997 bernilai lebih tinggi jika dibandingkan dengan nilai rata-rata $\mathrm{N}$-gain kelas kontrol yaitu 0.4055 . Adapun selisih nilai $\mathrm{N}$-gain antara kedua kelas tersebut yaitu sebesar 0,1942 atau $19,42 \%$.

Sebelum dilakukan analisis data uji t dari N-Gain kemampuan pemecahan masalah matematis pada kelas eksperimen dan kelas kontrol terlebih dahulu dilakukan uji prasyarat yakni uji normalitas dan uji homogenitas dari N-gain tersebut. Uji normalitas pada penelitian ini menggunakan teknik KolmogorovSmirnov sedangkan uji Homogenitasnya menggunakan Uji Levene. Adapun hasil uji normalitas data $\mathrm{N}$-gain kemampuan pemecahan maslaah matematis di kedua kelas dpaat dilihat pada tabel berikut.

Tabel 4. Hasil Uji Normalitas N-Gain Kemampuan Pemecahan Masalah Matematis Mahasiswa

\begin{tabular}{|c|c|c|c|c|c|c|c|}
\hline & \multirow[b]{2}{*}{ Kelas } & \multicolumn{3}{|c|}{ Kolmogorov-Smirnov ${ }^{\mathrm{a}}$} & \multicolumn{3}{|c|}{ Shapiro-Wilk } \\
\hline & & Statistic & Df & Sig. & Statistic & Df & Sig. \\
\hline \multirow[t]{2}{*}{ Gain } & Eksperimen & .108 & 40 & $.200^{\circ}$ & .947 & 40 & .060 \\
\hline & Kontrol & .122 & 40 & .137 & .947 & 40 & .061 \\
\hline
\end{tabular}

a. Lilliefors Significance Correction

*. This is a lower bound of the true significance.

Dari hasil uji normalitas pada tabel diatas, diketahui bahwa nilai sig. kelas eksperimen yaitu 0,200 dan kelas kontrol yaitu 0.137. Jadi, diperoleh bahwa nilai signifikansi kelas eksperimen dan kelas kontrol $>\alpha: 0,05$. Oleh karena itu, dapat disimpulkan bahwa data $\mathrm{N}$-gain kemampuan pemecahan masalah matematis kedua kelas tersebut berdistribusi normal. Selanjutnya, akan dilakukan uji homogenitas data kemampuan pemecahan maslaah matematis kedua kelas seperti yang terlihat pada tabel di bawah ini.

Tabel 5. Hasil Uji Homogenitas N-Gain Kemampuan Pemecahan Masalah Matematis Mahasiswa

\begin{tabular}{lllrrrr}
\hline & Levene Statistic & df1 & df2 & \multicolumn{2}{c}{ Sig. } \\
\hline Gain & Based on Mean & .735 & 1 & 78 & .394 \\
\cline { 2 - 6 } & Based on Median & .563 & 1 & 78 & .455 \\
\cline { 2 - 6 } & $\begin{array}{l}\text { Based on Median and with } \\
\text { adjusted df }\end{array}$ & .563 & 1 & 75.654 & .455 \\
\cline { 2 - 6 } & Based on trimmed mean & .719 & 1 & 78 & .399 \\
\hline
\end{tabular}


Dari hasil uji Levene, diketahui bahwa untuk dengan uji Levene nilai sig. Gain Based on Mean sebesar 0,394 $>\alpha: 0,05$ yang berarti kedua sampel mempunyai varians yang sama/homogen. Dengan demikian, data N-gain kemampuan pemecahan masalah matematis secara keseluruhan dapat disimpulkan memiliki varians yang sama atau homogen. Setelah pengujian prasyarat analisis data diperoleh bahwa N-Gain berdistribusi normal dan homogen maka analisis yang digunakan adalah analisis parametrik dengan menggunakan uji t. Adapun hasil pengujian hipotesis dengan menggunakan uji-t dapat dilihat pada tabel berikut.

Tabel 6. Hasil Uji-t Gain Kemampuan Pemecahan Masalah Matematis Mahasiswa

\begin{tabular}{|c|c|c|c|c|}
\hline & & & \multicolumn{2}{|c|}{ Gain } \\
\hline & & & $\begin{array}{c}\text { Equal } \\
\text { variances } \\
\text { assumed }\end{array}$ & $\begin{array}{c}\text { Equal } \\
\text { variances not } \\
\text { assumed }\end{array}$ \\
\hline \multirow{2}{*}{\multicolumn{2}{|c|}{$\begin{array}{l}\text { Levene's Test for Equality } \\
\text { of Variances }\end{array}$}} & $\mathrm{F}$ & .735 & \\
\hline & & Sig. & .394 & \\
\hline \multirow[t]{7}{*}{ t-test for Equality of Means } & & $\mathrm{T}$ & 13.030 & 13.030 \\
\hline & & $\overline{\mathrm{Df}}$ & 78 & 76.498 \\
\hline & & Sig. (2-tailed) & .000 & .000 \\
\hline & & Mean Difference & .1842571 & .1842571 \\
\hline & & Std. Error Difference & .0141415 & .0141415 \\
\hline & \multirow{2}{*}{$\begin{array}{l}95 \% \text { Confidence Interval } \\
\text { of the Difference }\end{array}$} & Lower & .1561036 & .1560949 \\
\hline & & Upper & .2124106 & .2124193 \\
\hline
\end{tabular}

Berdasarkan hasil analisis pengujian hipotesis yang dilakukan dan seperti yang terlihat pada tabel di atas dengan menggunakan uji- $\mathrm{t}$ pada taraf signifikansi 0,05 diperoleh nilai sig. (2-tailed) yaitu sebesar 0,000 lebih kecil dari taraf signifikansi 0,05 . Hal ini berarti $\mathrm{H}_{\mathrm{o}}$ ditolakdan Ha diterima. Jadi, dapat ditarik kesimpulan bahwa terdapat perbedaan yang signifikan peningkatan kemampuan pemecahan masalah matematis antara mahasiswa yang diajarkan dengan pembelajaran Group Investigation dengan mahasiswa yang diajarkan dengan pembelajaran langsung.

\section{Pembahasan Penelitian}

Berdasarkan hasil penelitian yang diperoleh di atas, maka akan dibahas hubungan beberapa faktor yang terkait dalam penelitian ini, yaitu faktor pembelajaran dan kemampuan pemecahan masalah matematis yang akan lebih rinci dijelaskan di bawah ini.

\section{a. Faktor Pembelajaran}

Salah satu faktor memberikan kontribusi yang cukup besar terhadap peningkatan kemampuan pemecahan masalah matematis mahasiswa adalah 
pembelajaran. Dalam penelitian ini pembelajaran yang diterapkan adalah model pembelajaran group investigation. Model pembelajaran kooperatif tipe group investigation yang dilakukan di kelas eksperimen dimulai dari pembagian kelompok mahasiswa yang heterogen (dari segi kemampuan, suku dna jenis kelamin) yang terdiri atas 5-6 orang tiap kelompoknya dan mahasiwa diberi kebebasan untuk memilih materi yang akan mereka pelajari. Adapun yang menjadi tujuan dibentuknya kelompok-kelompok kecil yaitu untuk memberi kebebasan dan kesempatan kepada setiap mahasiswa untuk menyelidiki, mencari solusi dari permasalahan, berinteraksi dan terlibat aktif dalam kegiatan belajar. Selain itu, dosen juga hanya memberikan bantuan kepada mahasiswa hanya bila diperlukan. Hal tersebut sangat berbeda denganpembelajaran yang dilakukan oleh dosen di kelas kontrol yang mana dosen menetapkan materi yang akan dipelajari dan dosen menyampaikan materi atau konsep kepada mahasiswa yang dilanjutkan dengan kegiatan tanya jawab dan penugasan sehingga hal ini menyebabkan mahasiswa kurang berinteraksi dan pasif dalam kegiatan pembelajaran. Dalam pembelajaran langsung dosen tidak pernah meminta mahasiswa membentuk kelompok. Mahasiswa diminta belajar secara individu.

Selain itu, pada model pembelajaran group investigation mahasiswa melakukan analisis informasi yang diperoleh untuk menyelesaiakna masalah yang diberikan dosen dan membuat rencana mengenai cara mempersentasekan hasil diskusi di depan kelas dengan tujuan agar mahasiswa yang lain terlibat satu sama lain dimana mahasiswa dapat memeriksa hasil diskusi kelompok yang maju untuk persentase dan mahasiswa lain memberikan masukan atau pertanyaan sehingga terjadi diskusi interaktif. Hal ini berbeda dengan pembelajaran langsung dimana biasanya mahasiswa hanya cukup menuliskan hasil penyelesaian masalah di depan kelas dan dosen langsung memeriksa jawaban siswa.

Jadi, berdasarkan hal yang disampaikan di atas dapat dilihat bahwa terdapat perbedaan pada proses pembentukan pengetahuan yang dilakukan oleh dosen dari kedua pembelajaran ini. Dalam hal ini, penerapan tahap demi tahap model pembelajaran group investigation dapat membuat siswa terlatih dalam mencari solusi permasalahan sehingga dapat meningkatkan kemampuan pemecahan masalah matematis mahasiswa. Perbedaan langkah-langkah pembelajaran antara dua model pembelajaran $t$ inilah yang dianggap mendukung hasil penelitian yaitu penerapan model pembelajaran Group Investigation sangat efektif digunakan dalam rangka meningkatkan kemampuan pemecahan masalah mahasiswa.

\section{b. Kemampuan Pemecahan Masalah Matematis}

Kemampuan pemecahan masalah matematis merupakan kemampuan yang dimiliki oleh mahasiswa dalam menemukan solusi dari permasalahan non rutin dengan menggunakan pengetahuan sebelumnya untuk mendapatkan pengetahuan yang baru. Berdasarkan hasil penelitian ini diperoleh bahwa kemampuan 
pemecahan masalah matematis siswa yang memperoleh pembelajaran group investigation dan yang diajar dengan pembelajaran langsung mengalami peningkatan berdasarkan data N-Gain. Namun, berdasarkan hasil pengujian hipotesis nilai $\mathrm{N}$-Gain kedua kelas tersebut menunjukkan bahwa terdapat perbedaan yang signifikan yaitu peningkatan kemampuan pemecahan masalah matematis siswa yang diajarkan dengan pembelajaran Group Investigation lebih tinggi daripada siswa yang diajarkan dengan pembelajaran langsung.

Pernyataan ini didukung juga dengan hasil penelitian kuasi eksperiment yang dilakukan oleh (Muhandaz, 2015) yang menyatakan kemampuan pemecahan masalah matematis siswa yang diajar dengan model pembelajaran kooperatif tipe investigasi kelompok lebih baik daripada siswa yang diajar dengan pembelajaran konvensional jika dilihat dari kemampuan awal siswa baik itu siswa yang memiliki kemampuan awal tinggi, sedang dan rendah. Dalam hal ini tes yang digunakan dalam penelitian adalah tes kemmapuan pemecahan masalah dna tes kemampuan awal siswa dan yang menjadi sampelnya adalah ssiswa MTsN. Selanjutnya, penelitian (Hija, A., Nirawati,R., dan Prihatiningtyas, 2016) menunjukkan kemampuan pemecahan masalah matematis siswa kelas yang diberikan model pembelajaran yang diberikan pembelajaran model GI lebih baik dibanding kelas yang diberikan pembelajaran konvensional. Penelitian tersebut merupakan penelitian true experiment dengan desain penelitian posttest only control group design dengan mengambil sampel siswa SMA. Selain itu, penelitian ini juga menganalisi peningkatan aktivitas dan respon siswa terhadap model pembelajaran.

Selain itu, penelitian (Huda, 2016) yang menunjukkan hal yang sama bahwa pembelajaran kooperatif tipe investigasi kelompok dapat meningkatkan kemampuan pemecahan masalah matematika siswa. Penelitian ini merupakan jenis penelitian PTK dan sampel penelitiannya merupakan siswa SMP. Hasil penelitian yang sama juga dinyatakan oleh (Lestari, 2016) yang mana hasil penelitian kuasi eksperimen ini menunjukkan bahwa peningkatan kemampuan pemecahan masalah matematis siswa pada kelas yang menerapkan pembelajaran group investigation berbantuan proyek secara signifikan lebih baik daripada siswa pada kelas yang menerapkan pembelajaran konvensional. Dalam hal ini, yang membedakan penelitian tersebut dengan penelitian ini adalah penggunaan pembelajaran group investigation berbantuan proyek dengan sampel siswa SMP.

Selain itu, hasil penelitian (Mutiawati, 2019) juga menunjukkan bahwa penggunaan model pembelajaran matematika tipe group investigation dalam pembelajaran terbukti dapat meningkatkan kemampuan pemecahan masalah matematis dan self-concept mahasiswa menjadi lebih baik. Dalam hal ini, penerapan model pembelajaran group investigation bukan hanya dapat meningkatkan kemampuan kognitif mahasiswa tetapi juga dapat meningkatkan 
sikap afektif mahasiswa. Penelitian yang lainnya yaitu hasil penelitian (Ningsih, 2019) juga menunjukkan hasil yang sama bahwa pemecahan masalah siswa yang mengikuti pembelajaran kooperatif tipe group investigation lebih tinggi dari kemampuan pemecahan masalah siswa yang mengikuti pembelajaran biasa. Dalam hal ini terdapat pengaruh model pemebelajaran kooperatif tipe Group Investigation terhadap kemampuan pemecahan masalah siswa. Penelitian kuasi eksperimen ini dilakukan kepada siswa MTsN yang secara tingkat kognitif jauh berbeda dengan kognitif mahasiswa. Berdasarkan beberapa hasil penelitian tersebut dapat disimpulkan bahwa kemampuan pemecahan masalah dengan menggunakan model pembelajaran group investigation dapat meningkatkan kemampuan pemecahan masalah matematis mahasiswa.

\section{KESIMPULAN}

Berdasarkan hasil penelitian seperti yang telah dikemukakan sebelumnya, diperoleh bahwa peningkatan kemampuan pemecahan masalah matematis siswa yang diajar dengan model pembelajaran Group Investigation lebih tinggi daripada siswa yang diajar dengan model pembelajaran langsung. Oleh karena itu, model pembelajaran kooperatif tipe Group Investigation dapat dijadikan sebagai salah satu model pembelajaran alternatif untuk meningkatkan kemampuan pemecahan maslaah matematis mahasiswa.

\section{DAFTAR PUSTAKA}

Amam, A. (2017). Penilaian Kemampuan Pemecahan Masalah Matematis Siswa SMP. Jurnal Teori Dan Riset Matematika (TEOREMA), 2(1), 39-46.

Hija, A., Nirawati,R., dan Prihatiningtyas, N. • (2016). Pengaruh Model Pembelajaran Group Investigation (GI) Terhadap Kemampuan Pemecahan Masalah Matematis Siswa Pada Materi Peluang Kelas X MIPA. Jurnal Pendidikan Matematika Indonesia, 1(1), 25-33.

Huda, M. (2016). Penerapan Pembelajaran Kooperatif Tipe Investigasi Kelompok Untuk Meningkatkan Kemampuan Pemecahan Masalah Matematika Siswa Pada Materi Persamaan Garis Lurus. INFINITY: Jurnal Ilmiah Program Studi Matematika STKIP Siliwangi Bandung, 5(1), 15-24.

Lestari, W. (2016). Penerapan Pembelajaran Kooperatif Tipe Group Investigation Berbantuan Proyek Terhadap Kemampuan Pemecahan Masalah Matematis Siswa SMP. Jurnal Matematika Dan Pendidikan Matematika, 1(2), 155-164.

Mariam Nasution. (2018). Konsep Standar Proses Dalam Pembelajaran Matematika. Logaritma : Jurnal Ilmu-Ilmu Pendidikan Dan Sains, 6(1), 120138. 
Muhandaz, R. (2015). Pengaruh Penerapan Model Pembelajaran Kooperatif Tipe Investigasi Kelompok Terhadap Kemampuan Pemecahan Masalah Matematis Siswa Kelas VIII MTsN Kota Padang. Suska Journal of Mathematics Education, 1(1), 35-44.

Mutiawati. (2019). Penerapan Model Pembelajaran Kooperatif Tipe Group Investigation dalam Menganalisis Kemampuan Pemecahan Masalah Matematis dan Self-Concept Mahasiswa. Journal of Education Science (JES), 5(1), 71-76.

Ningsih, F. (2019). Pengaruh Model Pembelajaran Group Investigation Terhadap Kemampuan Pemecahan Masalah Siswa Kelas VIII MTSN Kabupaten Kerinci. Journal Cendekia: Jurnal Pendidikan Matematika, 3(2), 351-362.

Polya, G. (1973). How To Solve 2nd Ed. Princeton: Princeton University Press.

Samo, D. (2017). Kemampuan Pemecahan Masalah Mahasiswa Tahun Pertama pada Masalah Geometri Konteks Budaya. Jurnal Riset Pendidikan Matematika, 4(2), 141-152.

Siradj. Y. (2014). Implementasi SCL (Student Centered Learning) Pada Pembelajaran Kuliah Jaringan Komputer (Studi Kasus: Politeknik Telkom). Jurnal Parameter, 24(1), 100-112.

Slavin, R. E. (2009). Cooperative Learning Teori, Riset dan Praktik. Bandung: Nusa Media.

Soemarmo, U dan Hendriana, H. (2014). Penilaian Pembelajaran Matematika. Bandung: PT Refika Aditama.

Trianto. (2013). Mendesain Model Pembelajaran Inovatif-Progresif. Konsep, Landasan, dan Implementasinya pada Kurikulum Tingkat Satuan Pendidikan (KTSP). Jakarta: Kencana Prenada Media Group.

Yarmayani, A. (2016). Analisis Kemampuan Pemecahan Masalah Matematis Siswa Kelas XI MIPA SMA Negeri 1 Kota Jambi. Jurnal Ilmiah DIKDAYA, $6(2), 12-19$.

Yunita, S., Andriani, L., dan Irma, A. (2018). Pengaruh Penerapan Model Pembelajaran Kooperatif Tipe Group Investigation terhadap Kemampuan Pemecahan Masalah Matematis ditinjau dari Motivasi Belajar Siswa Sekolah Menengah Pertama di Kampar. Juring (Journal for Research in Mathematics Learning), 1(1), 11-18. 